\title{
The Growth and Respiration of Nitrosocystis oceanus at Different Partial Pressures of Oxygen
}

\author{
BY K. GUNDERSEN* \\ Scripps Institution of Oceanography, University of California, \\ San Diego, La Jolla, California, U.S.A.
}

(Received 6 September 1965)

\begin{abstract}
SUMMARY
The following effects of different partial pressures of oxygen $p\left(\mathrm{O}_{2}\right)$ on the growth and on the oxidation of ammonium to nitrite by Nitrosocystis oceanus in liquid and on solid sea-water media were observed. Nearly pure $\mathrm{O}_{2}$ was toxic to the organism when it was exposed to the oxygen on agar medium. In normal air the growth on agar medium was variable; usually a large proportion of the inoculum organisms never started to divide. At low $p\left(\mathbf{O}_{2}\right)$ values the formation of microcolonies took place. In liquid medium the organism was less affected by high $p\left(\mathrm{O}_{2}\right)$ values than on agar. The lower limit of oxygen concentration which permitted oxidation of ammonium in liquid medium corresponded to about $0.05 \mathrm{ml} . \mathrm{O}_{2} / \mathrm{l}$. In respiration experiments a high $p\left(\mathrm{O}_{2}\right)$ in the gas phase resulted in twice as much oxygen uptake at the beginning as from air. Respiration at low $p\left(\mathrm{O}_{2}\right)$ was comparatively high. These results seem to indicate that the inorganic respiration is accelerated by an increased $p\left(\mathrm{O}_{2}\right)$ whereas growth is inhibited. Possible explanations are discussed.
\end{abstract}

\section{INTRODUCTION}

In an extensive search for organisms transforming ammonium to nitrite in the open ocean Watson (1961) showed the participation of a hitherto unknown nitrifying bacterium in this process. This organism oxidized ammonium to nitrite in an inorganic sea-water medium and assimilated carbon dioxide as sole carbon source. The organism therefore was classified as an obligately autotrophic nitrifier related to the soil nitrosomonas type of organisms. Since cysts were formed in liquid media the organism was placed with the genus Nitrosocystis as a new species, N. oceanus; morphological and physiological characteristics were given by Watson (1962b) and by Murray \& Watson $(1963,1965)$.

The present paper deals with the effects of different partial pressures of oxygen $p\left(\mathrm{O}_{2}\right)$ on Nitrosocystis oceanus.

\section{METHODS}

The organism. A culture of Nitrosocystis oceanus (Watson's strain; Watson, 1962 a) was used. The culture was purified from a heterotrophic contaminant by picking single isolated colonies which had developed on agar medium after incubation at low $p\left(\mathrm{O}_{2}\right)$.

* Present address: Department of Clinical Bacteriology, University of Gothenburg, Gothenburg SV, Sweden. 
Media. Stock cultures and liquid experimental cultures were grown in sea-water medium consisting of $2 \mathrm{~g}$. $\mathrm{NH}_{4} \mathrm{Cl}, 0 \cdot 1 \mathrm{~g} . \mathrm{K}_{2} \mathrm{HPO}_{4}, 5 \cdot 0 \mathrm{~g} . \mathrm{CaCO}_{3}$ in a mixture of

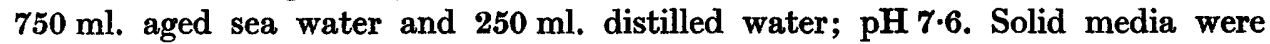
prepared from this liquid medium by adding $10 \mathrm{~g}$. 'Ion-agar' no. 2 (Oxoid)/l. For shaken cultures with dense suspensions of organisms a medium buffered with

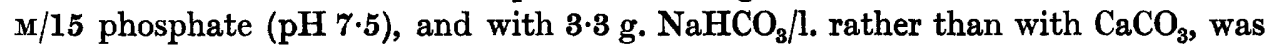
used.

The purity of the Nitrosocystis oceanus cultures was tested occasionally by transfer to a standard medium for marine heterotrophs which consisted of $\mathbf{5 \cdot 0} \mathrm{g}$. Bacto peptone, $0 \cdot 1 \mathrm{~g}$. $\mathrm{FePO}_{4}, 15.0 \mathrm{~g}$. Bacto agar in a mixture of $750 \mathrm{ml}$. aged sea water and $250 \mathrm{ml}$. distilled water; $\mathrm{pH} \mathrm{7 \cdot 5-7 \cdot 6.}$

Batch cultures. To obtain large crops of organism, cultures were prepared in 15-1. volumes of the liquid medium in 20-1. Pyrex flasks equipped with aeration and sampling devices. The inoculum consisted of $200 \mathrm{ml}$. of an actively nitrifying culture. Initially the batch culture was stirred with a Teflon-coated magnetic bar, but when growth was well established air filtered through a glasswool column was blown through the culture. As ammonium was consumed the $\mathrm{pH}$ value tended to decrease and more sterile $\mathrm{NH}_{4} \mathrm{Cl}$ and $\mathrm{CaCO}_{3}$ were added. Later it was necessary to add $\mathrm{NaHCO}_{3}$ to keep the $\mathrm{pH}$ above 7. In the most successful of a series of batch cultures a final crop of $5 \times 10^{9}$ organisms $/ \mathrm{ml}$. was obtained in 5 weeks. The organisms were harvested by centrifugation in a Sorvall continuous-flow centrifuge at $10,000 \mathrm{rev} . / \mathrm{min}$. after the particulate $\mathrm{CaCO}_{3}$ had been allowed to settle. The organisms were washed free from ammonium and nitrite with sterilized $75 \%(\mathrm{v} / \mathrm{v})$ sea water in distilled water. A reddish-brown sediment was obtained which was stored in $75 \%$ sea water at $4^{\circ}$. The ammonium-oxidizing capability of cold-stored suspensions of organisms decreased slowly, but it was found safe to use the organisms for respiration studies within 4 weeks after harvest.

Incubation. All incubations, when not otherwise stated, were made in darkness at room temperature $\left(25^{\circ} \pm 3^{\circ}\right)$. Anaerobic jars and desiccators were used as incubation chambers when growth in gas mixtures with different $p\left(\mathrm{O}_{2}\right)$ values was investigated. The ratio of gas volume to total culture volume in the jars always exceeded 100 . Cultures to be shaken during incubation were prepared in $\mathbf{2 5 0} \mathrm{ml}$. Erlenmeyer flasks with bored rubber stoppers equipped with a short piece of glass tubing attached to a vacuum rubber hose closable with a clamp. Sterile glycerol was used to secure tightness between stopper and flask neck. When gas mixtures other than air were used in the flasks a slight under-pressure served to keep the stoppers tight and as a check that tightness had been maintained during the experiment. A rotary shaker with an amplitude of $2 \mathrm{~cm}$. and turning at $300 \mathrm{rev} . / \mathrm{min}$. was used.

Counts of organisms were determined either by serial (decimal) dilutions in liquid medium followed by a check on nitrite production after 14 days-incubation, or by direct counting of the organisms in a Petroff-Hauser bacteria counter.

Nitrite determinations were made in a Spectronic 20 spectrophotometer at $540 \mathrm{~m} \mu$ after colour development with sulphanilamide and $N$-(1-naphthyl)-ethylenediamine solutions. In experiments where nitrite was to be determined in agar, the plates were poured with $20 \mathrm{ml}$. of agar medium. At the time of analysis the agar was cut into two pieces with a knife and the one half (about $10 \mathrm{ml}$.) further divided into smaller pieces and quantitatively transferred to $90 \mathrm{ml}$. nitrite-free water in a covered 
beaker. After at least $2 \mathrm{hr}$ of soaking the nitrite was determined as described above. The second half of the agar culture was used for microscopic examination.

Respiration studies. Oxygen uptake measurements were made in a conventional Warburg apparatus with $15 \mathrm{ml}$. flasks at $28^{\circ}$. When oxygen pressures other than atmospheric were used, the flask + manometer system was evacuated to a calculated pressure and refilled to atmospheric pressure with oxygen or nitrogen as desired while the flasks were shaking in the water bath. The organism suspensions were tipped from the side-arm of the flasks at zero time. Nitrite- $\mathrm{N}$ in the reaction mixtures was determined immediately after the conclusion of the last reading of the manometers.

Gas mixtures. When $p\left(\mathrm{O}_{2}\right)$ values different from that in air were used, the calculated volume of air was replaced after evacuation by pure nitrogen $\left(\mathbf{N}_{2}\right.$ minimum 99.996\%, v/v; The Liquid Carbonic Corp., San Diego, Calif., U.S.A.) or by oxygen (grade medically pure; Victor Equipment Co., Los Angeles, Calif., U.S.A.). The oxygen pressures given in the text and the tables below refer to the partial pressures of oxygen in the gas phase in the incubation jars or Warburg flasks. For convenience the relationship between the different partial pressures of oxygen in the gas phase most frequently used and oxygen dissolved at equilibrium in water of a salinity of $25 \%$ (which is close to the salinity of the media used) at $25^{\circ}$ is given in Table 1. An oxygen-free atmosphere was obtained by placing a dish with freshly mixed $\mathrm{NaOH}$ + pyrogallol in the incubation jar, evacuating to approximately $25 \mathrm{~mm}$. $\mathrm{Hg}$ and refilling with nitrogen. In the Warburg flasks oxygen was similarly removed by adding $0.2 \mathrm{ml}$. of the $\mathrm{NaOH}+$ pyrogallol mixture to the centre well instead of $\mathrm{KOH}$.

Table 1. Oxygen dissolved in water of $25 \%$ salinity at $25^{\circ}$ when in equilibrium with atmospheres of different partial pressures of oxygen, $p\left(\mathrm{O}_{2}\right)$

\begin{tabular}{|c|c|c|c|c|}
\hline \multicolumn{2}{|c|}{ Gas phase } & \multicolumn{3}{|c|}{ Dissolved oxygen } \\
\hline $\begin{array}{c}p\left(\mathrm{O}_{2}\right) \\
(\mathrm{mm} . \mathbf{H g})\end{array}$ & $\begin{array}{c}O_{2} \\
(\% \text { v/v })\end{array}$ & ml. $/ 1$. & mg. $/ 1$. & $\mathbf{m M}$ \\
\hline 684 & 90 & $22 \cdot 4$ & $32 \cdot 0$ & $1 \cdot 0$ \\
\hline 160 (air) & 21 & $5 \cdot 2$ & $7 \cdot 5$ & 0.23 \\
\hline 16 & $2 \cdot 1$ & 0.52 & $0 \cdot 75$ & 0.023 \\
\hline $\mathbf{5 \cdot 3}$ & 0.7 & $0 \cdot 17$ & $0 \cdot 25$ & 0.007 \\
\hline $1 \cdot 6$ & 0.21 & 0.05 & $0 \cdot 08$ & 0.002 \\
\hline
\end{tabular}

\section{RESULTS}

Growth and nitrite production in liquid medium

Early experiments showed that the oxidation of ammonium by Nitrosocystis oceanus in liquid shaken cultures was slower than in stationary cultures at the same temperature. There was also better growth and more dividing organisms in the static cultures than in the shaken ones. This observation was followed up by a series of experiments designed to examine what effect the oxygenation of the seawater medium might have on the growth of $N$. oceanus and on the oxidation of ammonium to nitrite. Since the mechanical shaking of the cultures was thought to introduce uncontrollable effects on these processes, it was decided to make the experiments with stationary cultures under atmospheres of different $p\left(\mathrm{O}_{2}\right)$ values. 
Figure 1 shows that the oxidation of ammonium took place over a wide range of oxygen concentrations. Maximum oxidation took place with normal air as gas phase. Small but significant amounts of nitrite (about a doubling of the amount carried over from the inoculum) were produced at the two lowest $p\left(\mathrm{O}_{2}\right)$ values; however, it cannot be excluded that this nitrite was preformed by the organisms and had merely leaked from them into the culture fluid during incubation.

Table 2. Growth of Nitrosocystis oceanus and production of nitrite in liquid static cultures incubated at different $p\left(\mathrm{O}_{2}\right)$ values

\begin{tabular}{|c|c|c|c|c|c|}
\hline \multicolumn{3}{|c|}{ First 2 weeks } & \multicolumn{3}{|c|}{ Next 2 weeks } \\
\hline $\begin{array}{c}p\left(\mathrm{O}_{2}\right) \\
(\mathrm{mm} . \mathrm{Hg})\end{array}$ & $\begin{array}{c}\mathrm{NO}_{2}-\mathrm{N} \\
(\mu \mathrm{g} . / \mathrm{ml} .)\end{array}$ & $\begin{array}{c}\text { Growth } \\
\text { index* }\end{array}$ & $\begin{array}{c}p\left(\mathrm{O}_{2}\right) \\
(\mathrm{mm} . \mathrm{Hg})\end{array}$ & $\begin{array}{c}\mathrm{NO}_{2}-\mathrm{N} \\
(\mu \mathrm{g} . / \mathrm{ml} .)\end{array}$ & $\begin{array}{c}\text { Growth } \\
\text { index* }\end{array}$ \\
\hline 684 & 0.5 & 1 & $\begin{array}{r}684 \\
160 \\
5 \cdot 3\end{array}$ & $\begin{array}{r}\mathbf{0} \cdot \boldsymbol{7} \\
\mathbf{3} \cdot \mathbf{0} \\
\mathbf{1} \cdot \mathbf{0}\end{array}$ & $\begin{array}{l}1 \\
\mathbf{3} \\
\mathbf{2}\end{array}$ \\
\hline 160 (air) & $15 \cdot 2$ & 3 & $\begin{array}{r}684 \\
160 \\
5 \cdot 3\end{array}$ & $\begin{array}{l}60 \cdot 0 \\
51 \cdot 0 \\
30 \cdot 0\end{array}$ & $\begin{array}{l}5 \\
5 \\
4\end{array}$ \\
\hline $5 \cdot 3$ & $3 \cdot 1$ & 2 & $\begin{array}{l}684 \\
160 \\
5 \cdot 3\end{array}$ & $\begin{array}{r}4.7 \\
10 \cdot 0 \\
4.5\end{array}$ & $\begin{array}{l}\mathbf{3} \\
\mathbf{4} \\
\mathbf{3}\end{array}$ \\
\hline
\end{tabular}

* The growth index is based on the appearance of nitrite in decimal dilutions in liquid medium from the original cultures. 1 means last positive tube dilution $10^{-1} ; 2$, dilution $10^{-2}$, etc. The test was made after 14-day incubation of the dilution tubes.

Table 2 shows the results of an experiment where three sets of identical cultures had first been kept for 2 weeks at three different oxygen pressures and then changed to higher and to lower $p\left(\mathrm{O}_{2}\right)$ values for the following 2 weeks. An initial incubation at $p\left(\mathrm{O}_{2}\right) 684 \mathrm{~mm}$. Hg harmed the organisms severely, resulting in less growth and less nitrite production during the subsequent incubation at lower $p\left(\mathrm{O}_{2}\right)$, and complete stagnation of the cultures kept continuously at this pressure. One further feature of this experiment was that the higher $p\left(\mathrm{O}_{2}\right)$ seemed to stimulate nitrite production and growth in those cultures which had initially been incubated in air. Short-term experiments with shaken cultures also showed clearly that oxygen stimulated the oxidation of ammonium to nitrite but at the same time inhibited the growth of the organism.

\section{Growth and nitrite production on agar medium}

The sensitivity of Nitrosocystis oceanus to oxygen was most clearly demonstrated when the organism on agar medium was exposed to the gas. The growth was completely inhibited in an atmosphere of $p\left(\mathrm{O}_{2}\right) 684 \mathrm{~mm}$. $\mathrm{Hg}$. The inhibition was irreversible since subsequent incubation in an atmosphere of lower $p\left(\mathrm{O}_{2}\right)$ which should otherwise have permitted growth did not result in resumed growth.

When plates on which growth had already been established during a period of incubation in air or at lower $p\left(\mathrm{O}_{2}\right)$ were subjected to the higher $p\left(\mathrm{O}_{2}\right)$, growth was also inhibited, but the oxidation of ammonium to nitrite continued, and at an increased rate (Table 3 ).

In air growth was very irregular; usually it was considerably delayed and took place only after a lag of 3 weeks or more (Fig. 2). On the other hand, the growth of 
Nitrosocystis oceanus at low $p\left(\mathrm{O}_{2}\right)$ was always rapid, with a lag period of less than 1 week (Fig. 2; Table 4). A $p\left(\mathrm{O}_{2}\right)$ corresponding to about one-tenth of the $p\left(\mathrm{O}_{2}\right)$ of air was optimal for growth on agar medium, although considerable growth was sometimes obtained as low as $p\left(\mathrm{O}_{2}\right) 5.3 \mathrm{~mm}$. $\mathrm{Hg}$.

Growth and nitrite production in agar cultures incubated at the same $p\left(\mathrm{O}_{2}\right)$ throughout a 4-week period as compared with growth and nitrite production in cultures incubated at higher or lower $p\left(\mathrm{O}_{2}\right)$ from the third week are shown in Table 3.

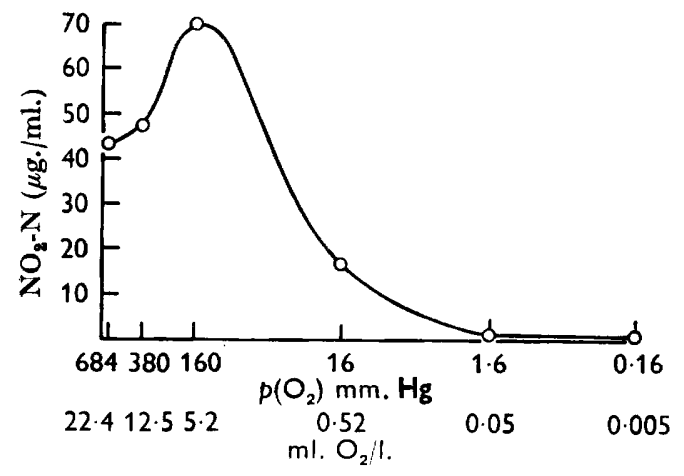

Fig. 1

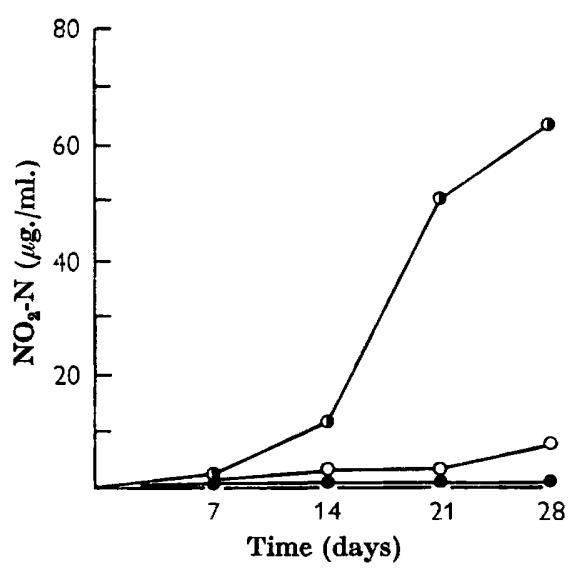

Fig. 2

Fig. 1. Nitrite production by Nitrosocystis oceanus in liquid sea-water medium incubated for 2 weeks under atmospheres of different values of $p\left(\mathrm{O}_{2}\right)$. The dissolved oxygen values (ml. $\mathrm{O}_{2} / \mathrm{l}$.) corresponding to the $p\left(\mathrm{O}_{2}\right)$ of the gas phase at equilibrium are added in the abscissa.

Fig. 2. Nitrite production by Nitrosocystis oceanus grown on agar medium in air (O), at $p\left(\mathrm{O}_{2}\right) 16 \mathrm{~mm}$. $\mathrm{Hg}(\mathrm{O})$ and at $p\left(\mathrm{O}_{2}\right) 684 \mathrm{~mm}$. $\mathrm{Hg}(\odot)$.

Table 3. Grozth of Nitrosocystis oceanus and nitrite production on agar medium after incubation at different $p\left(\mathrm{O}_{2}\right)$ values

First 2 weeks

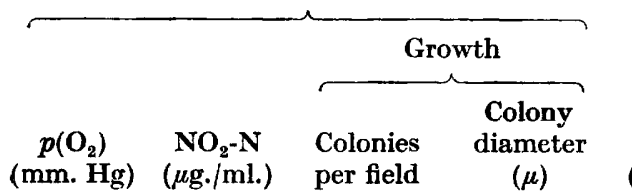

Next 2 weeks

\begin{tabular}{|c|c|c|c|}
\hline \multirow[b]{2}{*}{$\begin{array}{c}p\left(\mathrm{O}_{2}\right) \\
(\mathrm{mm} . \mathrm{Hg})\end{array}$} & \multirow[b]{2}{*}{$\begin{array}{c}\mathrm{NO}_{2}-\mathrm{N} \\
(\mu \mathrm{g} \cdot / \mathrm{ml} .)\end{array}$} & \multicolumn{2}{|c|}{ Growth } \\
\hline & & $\begin{array}{l}\text { Colonies } \\
\text { per field }\end{array}$ & $\begin{array}{c}\text { Colony } \\
\text { diameter } \\
(\mu)\end{array}$ \\
\hline 684 & $0 \cdot 2$ & $\mathbf{0}$ & - \\
\hline 160 & $0 \cdot 2$ & 0 & - \\
\hline $5 \cdot 3$ & 0.2 & $\mathbf{0}$ & - \\
\hline 684 & $\mathbf{3 5 \cdot 0}$ & $0 \cdot 8$ & $14 \cdot 0$ \\
\hline 160 & $27 \cdot 0$ & $1 \cdot 0$ & $46 \cdot 2$ \\
\hline $\mathbf{5} \cdot \mathbf{3}$ & $18 \cdot 1$ & 0.9 & $40 \cdot 8$ \\
\hline 684 & $21 \cdot 2$ & 0.5 & $11 \cdot 6$ \\
\hline 160 & $21 \cdot 2$ & $1 \cdot 0$ & $41 \cdot 5$ \\
\hline $\mathbf{5} \cdot \mathbf{3}$ & $14 \cdot 0$ & $0 \cdot 8$ & $37 \cdot 4$ \\
\hline
\end{tabular}

\footnotetext{
* From the inoculum.
} 
Table 4 shows clearly what took place on the agar media during incubation in air and at low $p\left(\mathrm{O}_{2}\right)$. On the low-oxygen plates the organism had already passed through three generations after 1 week whereas only half of the organisms grown in air had started to divide (most probably the apparent onset of growth in the latter case was false: the organisms may well have been in the dividing stage in the inoculum,

Table 4. Comparison of growth of Nitrosocystis oceanus on agar plates incubated in air $(A)$ and at $p\left(O_{2}\right) 5.3 \mathrm{~mm} . \mathrm{Hg}(B)$

\begin{tabular}{|c|c|c|c|c|}
\hline & & & & \\
\hline & $\mathbf{A}$ & $\mathbf{B}$ & $\mathbf{A}$ & $\mathbf{B}$ \\
\hline Colonies/field: & $2 \cdot 4^{*}$ & $2 \cdot 5$ & $0 \cdot 12$ & $2 \cdot 9$ \\
\hline Organisms/colony: & $1 \cdot 5$ & $8 \cdot 1$ & - & 一 \\
\hline Colony diameter $(\mu)$ : & - & 一 & $86 \cdot 5$ & $\mathbf{3 4} \cdot \mathbf{7}$ \\
\hline
\end{tabular}

* Mean values from 25 microscopical fields/plate; two plates.

Table 5. Oxygen consumption and nitrite production by washed suspensions of Nitrosocystis oceanus at different values of $p\left(\mathrm{O}_{2}\right)$

To each Warburg flask was added $1 \mathrm{ml}$. organism suspension equiv. $0 \cdot 2 \mathrm{mg}$. dry wt.; plus: to flask no. $1,2 \mathrm{ml}$. buffer; to flask no. $2,1 \mathrm{ml}$. buffer $+1 \mathrm{ml}$. $\mathrm{NH}_{4} \mathrm{Cl}, 150 \mathrm{~mm}$; to flask no. 8, $1 \mathrm{ml}$. $\mathrm{NH}_{4} \mathrm{Cl}, 150 \mathrm{~mm},+1 \mathrm{ml}$. $\mathrm{NaHCO}_{3}, 15 \mathrm{~mm}$. Total volume 3.0 ml. + 0.2 ml. $20 \% \mathrm{KOH}$ in the centre well, + pyrogallol also for the anaerobic flasks. The organism suspensions as well as the ammonium and bicarbonate solutions were made up in $\mathrm{M} / 15$ phosphate buffer $+3 \%(w / v)$ NaCl, pH 7.0. Bath temperature $28^{\circ}$. Shaking rate 65 strokes/min. Duration of experiment $6 \mathrm{hr}$.

\begin{tabular}{|c|c|c|c|c|c|c|}
\hline \multirow{2}{*}{$\underset{(\mathrm{mm} . \mathrm{Hg})}{p\left(\mathrm{O}_{2}\right)}$} & \multirow[b]{2}{*}{ Flask no. } & \multicolumn{2}{|c|}{ Oxygen consumed } & \multicolumn{2}{|c|}{ Nitrite produced } & \multirow{2}{*}{$\frac{\mathrm{O}_{2}^{*}}{\mathrm{NO}_{2}^{-}}$} \\
\hline & & $\mu l$ & $\mu \mathrm{M}$ & $\mu \mathrm{g} . \mathbf{N}$ & $\mu \mathrm{M}$ & \\
\hline 684 & $\begin{array}{l}1 \text { (endogenous) } \\
2 \\
3\end{array}$ & $\begin{array}{r}9 \\
164 \\
171\end{array}$ & $\begin{array}{l}0 \cdot 39 \\
7 \cdot 32 \\
7 \cdot 64\end{array}$ & $\begin{array}{r}0 \cdot 7 \\
67 \cdot 8 \\
74 \cdot 0\end{array}$ & $\begin{array}{l}0 \cdot 05 \\
4 \cdot 85 \\
5 \cdot 29\end{array}$ & $\begin{array}{l}\overline{1 \cdot 43} \\
1 \cdot 39\end{array}$ \\
\hline 160 (air) & $\begin{array}{l}1 \text { (endogenous) } \\
2 \\
3\end{array}$ & $\begin{array}{r}4 \\
141 \\
153\end{array}$ & $\begin{array}{l}0 \cdot 18 \\
6 \cdot 30 \\
6 \cdot 82\end{array}$ & $\begin{array}{r}0 \cdot 3 \\
62 \cdot 5 \\
69 \cdot 5\end{array}$ & $\begin{array}{l}0.02 \\
4.46 \\
4.96\end{array}$ & $\begin{array}{l}\overline{1 \cdot 38} \\
1 \cdot 35\end{array}$ \\
\hline 16 & $\begin{array}{l}1 \text { (endogenous) } \\
2 \\
3\end{array}$ & $\begin{array}{r}4 \\
126 \\
137\end{array}$ & $\begin{array}{l}0 \cdot 18 \\
5 \cdot 62 \\
6 \cdot 10\end{array}$ & $\begin{array}{r}0 \cdot 3 \\
56 \cdot 1 \\
58 \cdot 3\end{array}$ & $\begin{array}{l}0.02 \\
4.01 \\
4 \cdot 16\end{array}$ & $\begin{array}{l}-\overline{1 \cdot 37} \\
1 \cdot 43\end{array}$ \\
\hline $\mathbf{0}$ & $\begin{array}{l}1 \text { (endogenous) } \\
2 \\
3\end{array}$ & $\begin{array}{l}0 \\
0 \\
0\end{array}$ & - & $\begin{array}{l}0.02 \\
0.02 \\
0.02\end{array}$ & $\overline{-}$ & - \\
\hline
\end{tabular}

which had been taken from an actively nitrifying culture). The number of microcolonies/field agreed well after the first week. After 4 weeks, however, only the lowoxygen plates had the original number of colonies, whereas most of the air-grown 'colonies' had disappeared. On the other hand, the very few colonies which had developed were considerably larger than the colonies on the plates incubated at low $p\left(\mathrm{O}_{2}\right)$. 
Although Nitrosocystis oceanus was able to proliferate at quite low $p\left(\mathrm{O}_{2}\right)$, strict anaerobiosis was as harmful to the organism as a high $p\left(\mathrm{O}_{2}\right)$; growth did not occur in air at low $p\left(\mathrm{O}_{2}\right)$ when plates inoculated with $N$. oceanus had first been incubated for 2 weeks in the complete absence of oxygen.

\section{Respiration experiments}

The consumption of oxygen and the production of nitrite in systems of four different $p\left(\mathrm{O}_{2}\right)$ values are shown in Table 5. As expected, no nitrite was formed in the complete absence of oxygen. With the highest $p\left(\mathrm{O}_{2}\right)$ oxygen was taken up twice as fast as from normal air during the first $30 \mathrm{~min}$. of the experiment, but this high rate of respiration did not persist (Fig. 3). With a $p\left(\mathrm{O}_{2}\right)$ corresponding to one-tenth of the $p\left(\mathrm{O}_{2}\right)$ of air the respiration was lower but still surprisingly high in all of a series of experiments. More than one-third of the $300 \mu \mathrm{l}$. oxygen available in these flasks was consumed during the experimental period. The respiration generally was a little higher in flasks to which carbonate had been added than in flasks without any carbonate.

There was very little difference in the ratios $\mathrm{O}_{2}$ consumed: $\mathrm{NO}_{2}-$ produced, at the different $p\left(\mathrm{O}_{2}\right)$ values. The observed values decreased slightly below the theoretical for the oxidation of ammonium to nitrite:

$$
2 \mathrm{NH}_{4} \mathrm{Cl}+3 \mathrm{O}_{2} \rightarrow 2 \mathrm{HNO}_{2}+2 \mathrm{HCl}+2 \mathrm{H}_{2} \mathrm{O},
$$

which gives the $\mathrm{O}_{2}: \mathrm{NO}_{2}{ }^{-}$ratio $\mathbf{1} \cdot 50$.

\section{Addition of reducing substances}

The results of the experiments on the agar medium seemed to show that the organism was most sensitive to oxygen in the early stages of growth but that when growth was first established the organism became less sensitive. Since this might have been the result of the production by the organism itself of stabilizing substances, an experiment was run on agar medium to which sterile-filtered 14-daybatch culture fluid of Nitrosocystis oceanus ( $\mathrm{pH} 5 \cdot 8 ; \mathrm{NO}_{2}-\mathrm{N}, 324 \mu \mathrm{g} . / \mathrm{ml}$.) was added. The culture fluid was adjusted to $\mathrm{pH} 7 \cdot 8$ before sterilization and diluted in sterile medium to give final concentrations $25,2 \cdot 5,0 \cdot 25$ and $0.025 \%(\mathrm{v} / \mathrm{v})$. The plates were incubated in air and the growth followed microscopically for 2 weeks. The culture filtrate enhanced the growth of the organism to some degree; after 2 weeks tetrads and microcolonies consisting of 8-32 organisms were observed with the highest concentration, whereas the controls and the plates containing more dilute culture filtrate hardly showed any growth.

In the next series of experiments three different reducing substances (glutathione, Na thioglycollate, L-cysteine) were added to the agar medium in the following final concentrations: $0.2,0.02,0.002$ and $0.0002 \%(w / v)$. The plates were incubated in air. Cysteine and thioglycollate had no growth-promoting effect whereas $0.02 \%$ glutathione accelerated division. After 2 weeks the glutathione plates contained a large number of colonies, most consisting of $\mathbf{3 0}$ or more organisms, as compared to the single organisms, pairs and a few tetrads observed on the control plates. Also the production of nitrite was high in the $0.02 \%$ glutathione plates; the higher concentration was inhibitory, the lower without effect (Fig. 4). 
Yeast extract $(0 \cdot 1 \%, \mathrm{w} / \mathrm{v})$ also exerted a stimulatory effect on the growth of Nitrosocystis oceanus although different from the effect found with glutathione and low $p\left(\mathrm{O}_{2}\right)$ values. On yeast extract plates the colonies were few in number but considerably larger than in any previous experiment.

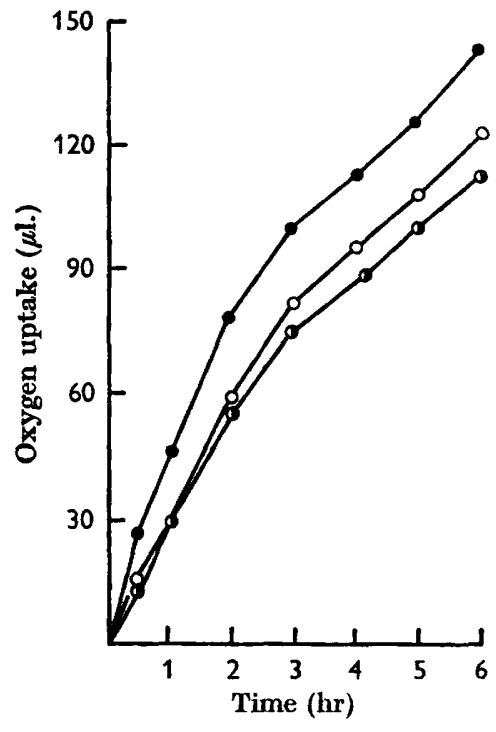

Fig. 3

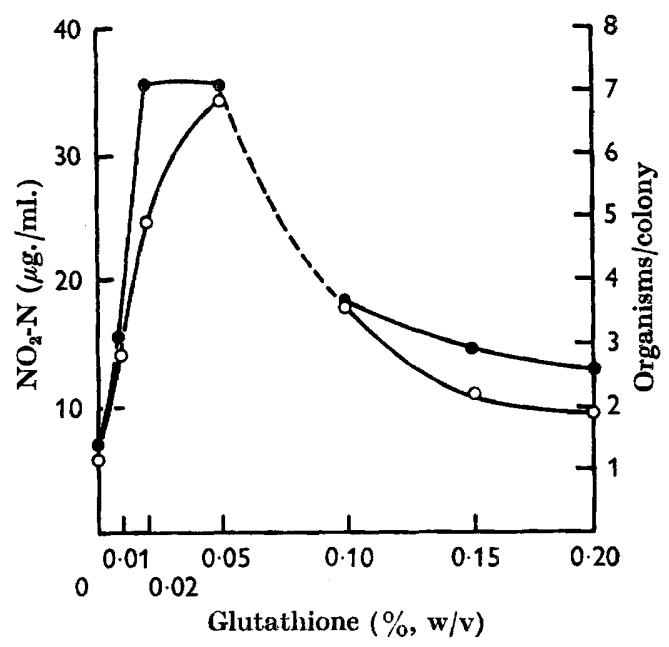

Fig. 4

Fig. 3. Oxygen uptake by suspensions of Nitrosocystis oceanus exposed to different values of $p\left(\mathrm{O}_{2}\right)$ in a Warburg apparatus. Symbols as Fig. 2.

Fig. 4. Growth and nitrite production by Nitrosocystis oceanus on agar medium to which different amounts of glutathione had been added. Incubation for 7 days in air. Organisms/ colony ; $\mathrm{NO}_{2}-\mathrm{N}, \mathrm{O}$.

\section{DISCUSSION}

That oxygen may be toxic to Nitrosocystis oceanus seems to have been well established by the present observations. Several other nitrifying bacteria and Thiobacillus thiooxidans have also been found to be irreversibly harmed or strongly inhibited by pure oxygen (Meyerhof, 1917; Schön, 1965; Gundersen, Carlucci \& Boström, 1966). It is a question whether the frequent failure to grow nitrifiers on agar media in air is due to oxygen inhibition. Division will take place in $N$. oceanus when the $p\left(\mathrm{O}_{2}\right)$ value is somewhat less than in normal air. However, when growth has once been established $N$. oceanus is no longer so sensitive to oxygen, except to very high concentrations. Thus there seems to exist a critical moment in the life of the organism during which growth will not begin unless the $p\left(\mathrm{O}_{2}\right)$ is decreased or the conditions in the medium made more reducing, e.g. by the addition of certain concentrations of glutathione.

It has been suggested (Gundersen, Boström \& Carlucci, 1966) that this sensitivity to oxygen has to do with the partition of reducing equivalents (electrons and reduced NAD or similar hydrogen carrier which have been produced by dehydrogenations of the inorganic substrate) between oxygen (energy metabolism) and the assimilatory system. This explanation seems to derive support from a finding by Schön (1965) 
that in Nitrobacter winogradskyi the assimilation of $\mathrm{CO}_{2}$ was completely inhibited by $95 \%(v / v)$ oxygen but not nitrite oxidation. It has been shown in respiration experiments with resting suspensions (e.g. Meyerhof, 1917; Hofman \& Lees, 1952) that the ammonium oxidizers consume 1.5 moles oxygen/mole ammonium oxidized. This implies that electrons and reducing equivalents from the substrate react readily with oxygen to form water (and a maximum of energy). However, when the oxidation of the substrate takes place according to the equation shown above, no reducing equivalents are available for the reduction of $\mathrm{CO}_{2}$ in assimilation and no growth can occur.

The possible significance of the redox potential on the activities of the nitrifying bacteria has occasionally been emphasized. ZoBell (1935) observed that growth and substrate oxidation of marine nitrifying bacteria had optima at different redox potentials, ammonium oxidation being optimal at $E_{h} 0.30$ to $0.55 \mathrm{~V}$ and growth at a somewhat lower potential. The growth-promoting effect of Nährstoff-Heyden (a preparation of egg albumin) on nitrosomonas was ascribed by Kingma Boltjes (1935) as a redox-stabilizing effect of the material. These findings, it is felt, are in favour of the explanation of the oxygen inhibition outlined above, but more comprehensive measurements of the redox fluctuations in cultures of nitrifying bacteria are desirable.

The age and the condition of the inoculum material apparently influences the sensitivity of Nitrosocystis oceanus to oxygen. When exposed to air on the surface of an agar plate, the majority of the organisms are incapable of growth, and only a small fraction may overcome the adverse condition and start dividing. Apparently the organism may itself, at a certain active stage of its life, adjust the environment in a direction favourable for its growth (provided the $p\left(\mathrm{O}_{2}\right)$ is not too high), possibly by the production of reducing substances.

The observation that oxygen was considerably less toxic in static liquid cultures than on agar medium seems to be explicable by the much shorter diffusion path of oxygen in the latter case, resulting in a constant high oxygen concentration at the cell surface. Nitrifying bacteria, in spite of their motility and basically aerobic nature, never accumulate at the surface of liquid media (as do many other motile aerobic bacteria) but are almost exclusively found near the bottom of tubes and flasks, eventually adhering to calcium carbonate or other particles. From an ecological point of view the finding that Nitrosocystis oceanus is able to oxidize ammonium to nitrite in sea-water medium containing very little dissolved oxygen is interesting. It has generally been considered by chemical oceanographers that nitrification in the ocean was only possible in well-oxygenated waters. The coincidence of nitrite and low oxygen contents usually has been taken as evidence of nitrate reduction rather than nitrification (Brandorst, 1959; Braarud \& Klem, 1931). However, if $N$. oceanus is widely distributed in the oceans of the world (as may reasonably be expected) then the possibility of nitrification in waters (and sediments) low in oxygen seems as likely as nitrate reduction except, of course, in completely anaerobic environments where nitrate reduction would be the only alternative. Virtually nothing is known about the organisms which carry out the final step of nitrification in the sea, namely the oxidation of nitrite to nitrate. However, if these organisms resemble their soil counterparts (e.g. nitrobacter species) in their relation to oxygen (Gundersen, Carlucci \& Boström, 1966) then the oxidation of 
nitrite in the sea would be much slower than the oxidation of ammonium at low oxygen concentrations, with the result that nitrite could accumulate until sufficient oxygen were again available for the complete nitrification.

This work was made possible through a Sverdrup Post-doctoral Fellowship in Oceanography and a travel grant from Anna Ahrenberg's Foundation for which the author is very grateful. The author also wishes to thank Dr C. E. ZoBell, head of the Marine Microbiology laboratory at Scripps Institution of Oceanography, for his active interest in the work and for much valuable advice.

\section{REFERENCES}

BraARUd, T. \& KLem, A. (1931). Hydrographical and chemical investigations in the coastal waters off Møre and in the Romsdalsfjord. Hvalrad. Skr. $1,48$.

BraNDHORST, W. (1959). Nitrification and denitrification in the eastern tropical north Pacific. J. Cons. perm. int. Explor. Mer. 25, 3.

Gundersen, K., Boström, K. \& CARLUCCI, A. F. (1966). Reducing equivalents in aerobic chemoautotrophic bacteria. J. theoret. Biol. (in the Press).

Gundersen, K., Carlucci, A. F. \& Boström, K. (1966). Growth of some chemoautotrophic bacteria at different oxygen tensions. Experientia (in the Press).

Hofman, T. \& Lees, H. (1952). The respiration of Nitrosomonas. Biochem. J. 52, xix.

KINGMA Boltues, T. Y. (1935). Untersuchungen über die nitrifizierenden Bakterien. Arch. Mikrobiol. 6, 79.

Meyerhof, O. (1917). Die Atmung des Nitritbildners und ihre Beeinflussung durch chemische Substanzen. Pflügers Arch. ges. Physiol. 166, 240.

Murray, R. G. E. \& Watson, S. W. (1963). An organelle confined within the cell wall of Nitrosocystis oceanus (Watson). Nature, Lond. 197, 211.

Murray, R. G. E. \& Watson, S. W. (1965). Structure of Nitrosocystis oceanus and comparison with Nitrosomonas and Nitrobacter. J. Bact. 89, 1594.

ScHöN, G. (1965). Untersuchungen über den Nutzeffekt von Nitrobacter winogradskyi Buch. Arch. Mikrobiol. 50, 111.

Watson, S. W. (1961). Autotrophic nitrification in the oceans. Bact. Proc. p. 34.

Watson, S. W. (1962a). Nitrosocystis oceanus sp.nov. Abstr. 8th int. Congr. Microbiol. B, $12,6$.

Watson, S. W. (1962b). Autotrophic nitrification in the ocean. Symposium on Marine Microbiology. Ed. by C. H. Oppenheimer, p. 73. Springfield, Ill., U.S.A.: Charles C. Thomas Publ.

ZoBELL, C. E. (1935). Oxidation-reduction potentials and the activity of marine nitrifiers. J. Bact. 29, 78. 